\title{
Investigation of Teachers Anger Control Problems
}

\author{
Munevver Mertoğlu \\ Correspondence: Munevver Mertoğlu, Istanbul Culture University, The Faculty of Law, CEHAMER, The Head of \\ Violence Research and Prevention Section, Istanbul, Turkey.
}

Received: October 2, 2018

doi:10.11114/jets.v6i12.3744
Accepted: October 24, 2018

Online Published: November 1, 2018

URL: https://doi.org/10.11114/jets.v6i12.3744

\begin{abstract}
The aim of this research is to determine the reasons for the anger levels of teachers and administrators considering some variables and to recommend sustainable changes to the school system. To analyse the data the Kruskal-Wallis test and other statistical measures were used. The results show that while there is no significant relationship with gender, other seniority and socio-economic status of teachers in the sixth, seventh, and eighth grade have meaningfully higher anger test points than primary and high school teachers. The external anger points are significantly lower among the teachers who like their professions versus those who do not like their profession. As a result, sustainable anger management programmes in schools via seminars or training sessions can contribute to changing teachers' attitudes towards their students by providing information about the nature of adolescence, and solutions to addressing the challenges of working with them.
\end{abstract}

Keywords: sustainable education, anger management program, adolescence

\section{Introduction}

Anger is generally defined as a strong feeling of displeasure, annoyance, and hostility of a person arising from indignation, being criticized, despised, or obstructed In the dictionary of psychology, anger is defined as an intensive and negative feeling occurring obstructed attacked, threatened, feeling bereft and generally results in the intention to cause harm to objects. In a broader sense, anger is also defined as one of the basic human feelings that has social, psychological, neurological, hormonal, environmental determinants and emerges when someone's plans, needs, and expectations acted out or from them feeling bereft or unfairly treated or his/her ego is threatened (Kassinove, Sukhodolsky 1995, pp.1-26; Maşaroğulları, Koçakgöl, 2011)

The cultural norms, families, social environments, schools and media have important roles in learning aggressive behaviours. Bandura (1986) argues that aggression is a type of behaviour that can be learned; it is not a part of human nature and human beings learn aggression from their environment as a result of imitation or identification. Therefore, families, and guardians at home, and teachers, administrators and other school personnel at schools have responsibilities to control their aggression so as not to create negative and traumatic effects on children.

Kağıtçıbaşı and Cemalciler (2017) point out that if children observe that the violent behaviours of adults are natural ways of solving problems, they start using these behaviours in their own lives.

The research made by Cummings, Vogel, Cummings and Sheikh (1989) into the effects of anger expression style of adults and the relationship with their children shows that the aggressive behaviours of adults create stress and anger in children and they give the same negative reactions towards adults.

At school, the main reason for violence committed by teachers against their students is related to how they effectively manage their classes, and their own anger in solving problems in the classroom. When teachers do not know how to solve problems in the classroom, they feel incompetent and desperate so that they become aggressive towards their own students. In the research by Mertoğlu (2013) on "the violence of teachers against students", the authors gathered data from Ministry of Education investigation files for the years between 1997 and 2005. The results show that while 60 per cent of teachers beat their students by hand or with an insrument the rest commit violence by insulting, threatening, pressurizing, ignoring or acting rudely to the students.

However, aggression and violent behaviour of adolescents cannot only be explained by the aggressive behaviour of parents and teachers. It is a fact that during the adolescence period, there are rapid physical, psychological, mental and social changes, and most children cannot cope with these changes so quickly, and consequently they become more 
violent and aggressive (Healy, J., 1997, p.127-130-137). For example, the prefrontal cortex of the brain becomes the growth centre; new neurons increase in the prefrontal cortex, and they may cause the speech centre to slow down and aggression in adolescents. Another research made on violent children shows that there is a correlation between aggressiveness and glucose levels in the prefrontal cortex. The decrease in blood circulation and lack of glucose consumption in the brain can cause aggression among adolescents (Ak, Sayar, 2002, pp. 155-158).

Parents, teachers and administrators are expected to understand the nature of the adolescence period and to have supportive and democratic relationships with the students (Bandura, 1986). The research into "the effects of adult behaviour on the aggression of adolescents" shows that students whose fathers have a democratic approach have lower anger test points than the ones whose mothers are protective and ambiguous in their attitudes. This means that their levels of violence dramatically change when the adolescents express themselves clearly, courageously, and use their communicative skills effectively.

At school, it is crucial to have a peaceful and positive school atmosphere to help the students' personal development and academic success (Frenzel et al., 2015). Therefore, teachers and administrators and other school personnel are firstly responsible to find out the sources of violence in school's and secondly to take the necessary precautions to stop it.

Aim of The Research: The aim of this study to find out the reasons for the level and type of aggression in teachers and administrators to determine its relation with its variables and to recommend necessary precautions.

\section{Method}

\section{Sampling}

The sampling of this research covers 137 teachers in 12 schools in the town of Seferihisar, İzmir. The Trait Anger and Anger Expression Scale and personal data of the teachers are used in the study. The Trait Anger and Anger Expression Scale was developed by Spielberger (1983) and has a four-point Likert Scale but only article 34 is categorized as "never", "sometimes", "rather", "absolutely". In this scale, the first ten articles measure trait anger (TA), and the second ten articles measure state-trait anger. The Anger Management Scale is a combination of eight articles;11,14,18,21,25,28,30,34; External Anger is 12,17,19,22,24,29,32,33; and Internal Anger 13,15,16,20,23,26, 27,31. The results determined from high trait anger, bound points show that anger level is high; from high anger management, bound points indicate that anger is under control; from high external anger, bound points indicate that anger is easily expressed and from internal high anger, bound points indicate that anger is repressed.

To analyse the results, for non-parametric data the Kruskal-Wallis test was used and for averages mode, median, and standard deviation were used.

In this research, the questions below were asked (bound problems);

1. What are the trait-anger, state-trait anger, anger management scale, external and internal levels of teachers and administrators?

2. Are there any meaningful relationships between the average points of trait anger, anger management scales, internal and external anger of teachers and

the name of the schools that teachers and administrators work,

the type of schools (primary, secondary, and high schools)

the socio-economic levels of school students

the branches of teachers

the gender and rank of teachers

whether teachers and administrators like their professions

\section{Findings}

\section{Analysis with the Sampling Group}

The distribution of the teachers who participated in this survey is; $37 \%$ male and $63 \%$ female; $42 \%$ primary and $43 \%$ branch teachers and 15\% administrators. The rank of teachers are 5\% between 0 and 10 years; $24 \%$ between 11 and 20 years; $36 \% 21$ and 30 years and 5\% have thaught for 31 years.

\section{The Analysis According to Trait Anger of Teachers}




\subsection{Does the Trait Anger of Teachers Change According to the Schools Where They Work?}

Table 1 . The average points of the trait anger of teachers working in different schools

\begin{tabular}{|c|c|c|c|c|c|c|c|c|c|}
\hline \multirow{3}{*}{$\begin{array}{c}\text { Code of the } \\
\text { School }\end{array}$} & \multicolumn{3}{|c|}{ Means } & & & $\begin{array}{l}95 \% \mathrm{C} \\
\text { Interva }\end{array}$ & $\begin{array}{l}\text { lence } \\
\text { Mean }\end{array}$ & & \\
\hline & & & & & & Lower & Upper & & \\
\hline & $\mathrm{N}$ & Score & $\%$ & Std. Dev & Std. Error & Bound & Bound & Min. & Max. \\
\hline 6 & 10 & 14.2 & $36 \%$ & 3.8 & 1.2 & 11.5 & 16.9 & 10 & 21 \\
\hline 7 & 4 & 15.25 & $38 \%$ & 3.3 & 1.7 & 10 & 20.5 & 11 & 19 \\
\hline 11 & 12 & 15.42 & $39 \%$ & 3.2 & 0.9 & 13.4 & 17.4 & 11 & 20 \\
\hline 8 & 21 & 15.86 & $40 \%$ & 3.4 & 0.7 & 14.3 & 17.4 & 11 & 27 \\
\hline 1 & 10 & 17.1 & $43 \%$ & 3.6 & 1.1 & 14.5 & 19.7 & 10 & 23 \\
\hline 2 & 22 & 17.32 & $43 \%$ & 3.6 & 0.8 & 15.7 & 18.9 & 10 & 26 \\
\hline 9 & 5 & 17.4 & $44 \%$ & 3.2 & 1.4 & 13.4 & 21.4 & 13 & 20 \\
\hline 4 & 12 & 17.58 & $44 \%$ & 4.8 & 1.4 & 14.6 & 20.6 & 11 & 29 \\
\hline 12 & 12 & 17.83 & $45 \%$ & 3.9 & 1.1 & 15.4 & 20.3 & 11 & 25 \\
\hline 10 & 9 & 19.89 & $50 \%$ & 2.9 & 1.0 & 17.7 & 22.1 & 17 & 26 \\
\hline 3 & 7 & 20 & $50 \%$ & 5.3 & 2.0 & 15.1 & 24.9 & 14 & 30 \\
\hline 5 & 7 & 20 & $50 \%$ & 3.1 & 1.2 & 17.2 & 22.8 & 16 & 24 \\
\hline Total & 131 & 17.13 & $43 \%$ & 3.9 & 0.3 & 16.5 & 17.8 & 10 & 30 \\
\hline
\end{tabular}

In the table above, the name of the schools are coded and the average points of trait anger change between $36 \%$ and $50 \%$ according to different schools. To find out the statistically meaningful differences among averages, a Kruskal-Wallis test was performed and there are statistically meaningful differences. as $\mathrm{p}=0.01<0.05$ in this test analysis.

\subsection{Do the Levels of the Teachers' Trait Anger Change According to the Socio-Economic Levels of Schools?}

Table 2. The trait anger points of the teachers according to socio-economic levels

\begin{tabular}{ccccccc}
\hline $\begin{array}{c}\text { Socio-economic } \\
\text { Level }\end{array}$ & $\mathrm{N}$ & Score & $\%$ & & Min. & Max. \\
\hline Low & 18 & 18.94 & $47 \%$ & 4.4 & 11 & 30 \\
Medium & 57 & 16.70 & $42 \%$ & 4.0 & 10 & 29 \\
High & 56 & 16.98 & $42 \%$ & 3.6 & 10 & 26 \\
Total & 131 & 17.13 & $43 \%$ & 3.9 & 10 & 30
\end{tabular}

According to the Kruskal-Wallis test, $\mathrm{p}=0.034<0.05$. Accordingly, there are no meaningful differences between the trait anger of the teachers and the socio-economic level of the schools where they work.

2.3 Do the Trait Anger Levels of Teachers Change According to the Schools (Primary, Secondary, High Schools) Where They Work?

Table 3. The points of trait anger levels according to the type of schools

\begin{tabular}{|c|c|c|c|c|c|c|c|c|}
\hline \multirow[b]{2}{*}{ Type of School } & \multirow[b]{2}{*}{$\mathrm{N}$} & \multirow[b]{2}{*}{ Mean } & \multicolumn{6}{|c|}{$\begin{array}{l}95 \% \text { Confidence } \\
\text { Interval for Mean }\end{array}$} \\
\hline & & & $\begin{array}{l}\text { Std. } \\
\text { Dev. }\end{array}$ & $\begin{array}{l}\text { Std. } \\
\text { Error }\end{array}$ & $\begin{array}{l}\text { Lower } \\
\text { Bound }\end{array}$ & $\begin{array}{l}\text { Upper } \\
\text { Bound }\end{array}$ & Min. & Max. \\
\hline Primary & 66 & 16.29 & 3.75 & 0.46 & 15.37 & 17.21 & 10 & 27 \\
\hline Secondary & 53 & 18.08 & 3.80 & 0.52 & 17.03 & 19.12 & 10 & 30 \\
\hline High School & 12 & 17.58 & 4.76 & 1.37 & 14.56 & 20.61 & 11 & 29 \\
\hline Average & 131 & 17.13 & 3.93 & 0.34 & 16.45 & 17.81 & 10 & 30 \\
\hline
\end{tabular}

According to the Kruskal-Wallis test, $\mathrm{p}=0.034<0.05$. Consequently, there are meaningful average differences in the trait anger of the teachers according to the type of schools where they work. As can be seen in the table, while the trait anger points of the primary school teachers and their maximum values are meaningfully lower than other schoolteachers, the secondary school teachers have the highest trait anger points in this table. 


\subsection{How Do the Trait Anger Levels of Teachers Change According to Their Branches?}

Table 4. The anger trait points of teachers according to their branches

\begin{tabular}{|c|c|c|c|c|c|c|c|c|}
\hline \multirow[b]{2}{*}{ Branch } & \multirow[b]{2}{*}{$\mathbf{N}$} & \multirow[b]{2}{*}{ Mean } & \multirow[b]{2}{*}{ Std. Dev. } & \multirow[b]{2}{*}{$\begin{array}{l}\text { Std. } \\
\text { Error }\end{array}$} & \multicolumn{2}{|c|}{$\begin{array}{l}\text { 95\% Confidence } \\
\text { Interval for Mean }\end{array}$} & \multirow[b]{2}{*}{ Min. } & \multirow[b]{2}{*}{ Max. } \\
\hline & & & & & $\begin{array}{l}\text { Lower } \\
\text { Bound }\end{array}$ & $\begin{array}{l}\text { Upper } \\
\text { Bound }\end{array}$ & & \\
\hline Primary School Teacher & 54 & 16.15 & 3.9 & 0.5 & 15.1 & 17.2 & 10 & 27 \\
\hline Branch Teacher & 55 & 18.20 & 3.9 & 0.5 & 17.2 & 19.2 & 10 & 30 \\
\hline Administrators & 19 & 16.89 & 3.6 & 0.8 & 15.2 & 18.6 & 10 & 24 \\
\hline Average & 128 & 17.14 & 3.9 & 0.3 & 16.5 & 17.8 & 10 & 30 \\
\hline
\end{tabular}

Kruskal-Wallis test results show that there are statistically meaningful differences in the trait anger points of the teachers according to their branches, as $\mathrm{p}=0.012<0.05$.In Table 4 , the points of the trait anger of primary school teachers are meaningfully lower than other groups of teachers. The branch teachers have the highest trait anger points and their maximum values are greater than other teachers. The administrators, who are the smallest sample group, have maximum trait anger average points that are lower than branch teachers.

As a result, there are no meaningful differences in the trait anger of teachers regarding their gender, rank, or their interest in their professions, either in Kruskal-Wallis or Mann-Whitney U tests.

\section{The Analysis of State-Trait Anger Level of Teachers}

\subsection{Do the Teachers'State-Trait Anger Test Points Change According to the Schools Where They Work?}

Table 5. The division on state-trait anger points of teachers according to schools

\begin{tabular}{|c|c|c|c|c|c|c|c|c|c|}
\hline \multirow{2}{*}{$\begin{array}{l}\text { Code } \\
\text { of the } \\
\text { School }\end{array}$} & \multirow[b]{2}{*}{$\mathrm{N}$} & \multicolumn{2}{|c|}{ Mean } & \multirow[t]{2}{*}{ Std. } & \multicolumn{3}{|c|}{$\begin{array}{l}\text { 95\% Confidence } \\
\text { Interval for Mean }\end{array}$} & \multirow[b]{2}{*}{ Min. } & \multirow[b]{2}{*}{$\operatorname{Max}$} \\
\hline & & Score & $\%$ & & $\begin{array}{l}\text { Std. } \\
\text { Error }\end{array}$ & $\begin{array}{l}\text { Lower } \\
\text { Bound }\end{array}$ & $\begin{array}{l}\text { Upper } \\
\text { Bound }\end{array}$ & & \\
\hline 4 & 12 & 21.00 & $53 \%$ & 8.0 & 2.3 & 15.92 & 26.08 & 0 & 29 \\
\hline 5 & 7 & 21.14 & $53 \%$ & 2.6 & 1.0 & 18.73 & 23.56 & 17 & 24 \\
\hline 7 & 4 & 21.25 & $53 \%$ & 5.8 & 2.9 & 12.03 & 30.47 & 15 & 29 \\
\hline 10 & 9 & 22.00 & $55 \%$ & 2.4 & 0.8 & 20.12 & 23.88 & 19 & 27 \\
\hline 1 & 10 & 21.80 & $55 \%$ & 3.5 & 1.1 & 19.33 & 24.27 & 15 & 28 \\
\hline 2 & 22 & 22.36 & $56 \%$ & 2.7 & 0.6 & 21.16 & 23.57 & 16 & 28 \\
\hline 9 & 5 & 22.40 & $56 \%$ & 3.2 & 1.4 & 18.42 & 26.38 & 18 & 25 \\
\hline 12 & 12 & 22.42 & $56 \%$ & 3.5 & 1.0 & 20.18 & 24.66 & 18 & 29 \\
\hline 8 & 21 & 22.71 & $57 \%$ & 3.3 & 0.7 & 21.22 & 24.20 & 16 & 29 \\
\hline 11 & 12 & 22.75 & $57 \%$ & 2.9 & 0.8 & 20.91 & 24.59 & 19 & 27 \\
\hline 6 & 10 & 22.90 & $57 \%$ & 3.7 & 1.2 & 20.26 & 25.54 & 19 & 29 \\
\hline 3 & 7 & 25.43 & $64 \%$ & 4.9 & 1.8 & 20.93 & 29.92 & 18 & 31 \\
\hline Total & 131 & 22.37 & $56 \%$ & 3.9 & 0.3 & 21.69 & 23.06 & 0 & 31 \\
\hline
\end{tabular}

According to the schools where they work, the averages of state-trait anger points of teachers show changes between 53\% and $64 \%$. Kruskal-Wallis test results indicate that the differences among the averages are not meaningful, as $\mathrm{p}>0.05$.

\section{The Analysis of Anger Management Levels of Teachers}

Table 6. Anger management test points of teachers according to type of schools

\begin{tabular}{|c|c|c|c|c|c|c|c|c|c|}
\hline \multirow[b]{2}{*}{ Type of School } & \multirow[b]{2}{*}{$\mathrm{N}$} & \multicolumn{2}{|c|}{ Mean } & \multicolumn{6}{|c|}{$\begin{array}{l}95 \% \text { Confidence } \\
\text { Interval for Mean }\end{array}$} \\
\hline & & Score & $\%$ & $\begin{array}{l}\text { Std. } \\
\text { Dev. }\end{array}$ & $\begin{array}{l}\text { Std. } \\
\text { Error }\end{array}$ & $\begin{array}{l}\text { Lower } \\
\text { Bound }\end{array}$ & $\begin{array}{l}\text { Upper } \\
\text { Bound }\end{array}$ & Min. & Max. \\
\hline Primary & 66 & 25.86 & $81 \%$ & 5.0 & .62 & 24.63 & 27.09 & 14 & 32 \\
\hline Secondary & 53 & 23.83 & $74 \%$ & 4.5 & .62 & 22.58 & 25.08 & 16 & 32 \\
\hline High School & 12 & 22.83 & $71 \%$ & 7.6 & 2.18 & 18.03 & 27.63 & 0 & 29 \\
\hline Total & 131 & 24.76 & $77 \%$ & 5.2 & .45 & 23.87 & 25.66 & 0 & 32 \\
\hline
\end{tabular}

In Table 6 , as $\mathrm{p}=0.029<0.05$, anger management of the teachers for the school types shows that there are meaningful differences in this regard.

\subsection{Do the Anger Management Test Points of the Teachers Change According to Whether They Like Their Profession?}

Table 7. The anger management test points of teachers according to their interest in their profession

\begin{tabular}{|c|c|c|c|c|c|}
\hline \multirow[b]{2}{*}{ Interest } & \multirow[b]{2}{*}{$\mathrm{N}$} & \multicolumn{2}{|c|}{ Mean } & \multirow{2}{*}{$\begin{array}{l}\text { Std. } \\
\text { Dev. }\end{array}$} & \multirow{2}{*}{$\begin{array}{c}\text { Std. } \\
\text { Error }\end{array}$} \\
\hline & & Score & $\%$ & & \\
\hline Like it a lot & 108 & 25.42 & $79 \%$ & 5.145 & .495 \\
\hline A necessity & 9 & 21.56 & $67 \%$ & 4.246 & 1.415 \\
\hline
\end{tabular}


The anger management test points of teachers who like their professions are $79 \%$ higher than those who consider it something obligatory. As in the Mann-Whitney $U$ analysis test $p=0.015<0.05$, the average differences are statistically meaningful.

Statistically meaningful differences are detected in the anger management test points for the type and socio-economic levels of schools, branch of teachers (primary school teachers, branch teachers, administrators), rank and gender of teachers in the analysis.

\section{Analysis of the Internal Anger Level of Teachers}

To determine the internal anger test points of teachers, the name and type, and socio-economic level of schools, the rank, branch, and gender of teachers and their interest in their profession are analysed. The results of the analysis indicated that there are no statistically meaningful differences in the internal anger levels of teachers according to any of the tested variables.

\section{Analysis of the External Anger Level off Teachers}

According to the Kruskal-Wallis test results, there are meaningful average differences depending on the type of schools where the teachers work (primary, secondary and high school), and the branch of teachers in the external anger scale of teachers.

\subsection{Do the Points of External Anger Test Points of Teachers Change According to the Type of Schools?}

Table 8 . The external anger test points of teachers change in relation to type of schools

\begin{tabular}{|c|c|c|c|c|c|c|c|c|c|}
\hline \multirow[b]{2}{*}{ Type of School } & \multirow[b]{2}{*}{$\mathrm{N}$} & \multicolumn{2}{|c|}{ Mean } & \multicolumn{6}{|c|}{$\begin{array}{l}\text { 95\% Confidence } \\
\text { Interval for Mean }\end{array}$} \\
\hline & & Score & $\%$ & $\begin{array}{l}\text { Std. } \\
\text { Dev. }\end{array}$ & $\begin{array}{l}\text { Std. } \\
\text { Error }\end{array}$ & $\begin{array}{l}\text { Lower } \\
\text { Bound }\end{array}$ & $\begin{array}{l}\text { Upper } \\
\text { Bound }\end{array}$ & Min. & Max. \\
\hline Primary & 66 & 15.15 & $47 \%$ & 3.1 & 0.38 & 14.39 & 15.92 & 10 & 26 \\
\hline Secondary & 53 & 16.40 & $51 \%$ & 2.9 & 0.40 & 15.59 & 17.20 & 9 & 28 \\
\hline High School & 12 & 14.42 & $45 \%$ & 4.7 & 1.35 & 11.44 & 17.39 & 4 & 24 \\
\hline Total & 131 & 15.59 & $49 \%$ & 3.3 & 0.28 & 15.03 & 16.15 & 4 & 28 \\
\hline
\end{tabular}

In the table, the external anger test points of the secondary school teachers are 51\% higher than the other school teachers. For the Kruskal-Wallis, test $\mathrm{p}=0.015<0.005$, and the average differences are statistically meaningful.

6.2 Are There Any Changes in the External Anger Test Points of Teachers in Accordance With Their Branches?

Table 9. The external anger level of teachers according to the branch of teachers

\begin{tabular}{|c|c|c|c|c|c|c|c|c|c|}
\hline \multirow[b]{2}{*}{ Branch } & \multirow[b]{2}{*}{$\mathrm{N}$} & \multicolumn{2}{|c|}{ Mean } & \multicolumn{6}{|c|}{$\begin{array}{l}95 \% \text { Confidence } \\
\text { Interval for Mean }\end{array}$} \\
\hline & & Score & $\%$ & $\begin{array}{l}\text { Std. } \\
\text { Dev. }\end{array}$ & $\begin{array}{l}\text { Std. } \\
\text { Error }\end{array}$ & $\begin{array}{l}\text { Lower } \\
\text { Bound }\end{array}$ & $\begin{array}{l}\text { Upper } \\
\text { Bound }\end{array}$ & Min. & Max. \\
\hline $\begin{array}{c}\text { Primary School } \\
\text { Teacher }\end{array}$ & 54 & 14.91 & $47 \%$ & 3.229 & 0.439 & 14.03 & 15.79 & 10 & 26 \\
\hline Branch Teacher & 55 & 15.93 & $50 \%$ & 3.393 & 0.458 & 15.01 & 16.84 & 4 & 28 \\
\hline Administrators & 19 & 16.74 & $52 \%$ & 2.705 & 0.621 & 15.43 & 18.04 & 9 & 22 \\
\hline Total & 128 & 15.62 & $49 \%$ & 3.275 & 0.289 & 15.04 & 16.19 & 4 & 28 \\
\hline
\end{tabular}

The external anger points of the primary school teachers are $47 \%$ higher than branch teachers and administrators. The Kruskal-Wallis test, $\mathrm{p}=0.008<0.005$, results indicate that there are meaningful statistical differences in the averages.

In this survey, the names and socio-economic level of schools, rank and gender of teachers and their interest in their profession were analysed and it was found that there are no significant differences in the external anger tests points of the teachers.

\section{Results, Discussion and Recommendations}

The results of this survey made with the teachers working in the 12 different schools including primary, secondary, and high schools in the town of Seferihisar, İzmir are discussed below;

1. It is determined that teachers and administrators generally do not have problems with their trait anger, state-trait anger, anger management, external and internal anger levels.

2. When the trait anger, state-trait anger, anger management, external and internal anger of teachers and administrators are analysed taking into consideration the variables such as the schools where teachers work, type of school (primary, secondary, high schools), branch, gender and rank of teachers:

a) It is determined that the averages of trait anger test points of teachers change meaningfully with the type of schools (primary, secondary, high schools) while there aren't any changes in their ranks, genders and whether they like their professions. 
b) The average points of the state-trait anger of teachers are meaningfully lower than the other variants, such as type of school, socio-economic level of schools and gender and rank of teachers.

c) It is determined that the external anger points of teachers do not change according to the schools where they work, type of school, branch, gender, rank of teachers, whether they like their professions or the socio-economic levels of students as well.

d) As a result, it is found out that the external anger test points of the branch teachers and secondary school teachers are $51 \%$ higher than those of the primary and high school teachers.

When the socio-economic level of students are detected, there are no meaningful differences in the research. There may be two reasons for this result:

a) The socio-economic level of the students are not classified properly by the Ministry of Education in Seferihisar, Izmir.

b) There are no meaningful differences in the students' anger feelings regarding their socio-economic levels.

In this research, it is determined that there are no meaningful differences between the gender, and rank of teachers' test points. This result supports other research (Yaman, Türker, 2011), which showed similar results on the teachers' anger levels. Male teachers are more aggressive towards students but these attitudes decrease with age (Mertoğlu, 2015; Çalı, 2012). In other research, it has been found out that although males and females have similar anger feelings, males' anger feelings are more aggressive because they are more tolerated and accepted by the cultural norms.

If teachers' trait anger and anger expression scales show meaningful differences in the schools where they work, there are other factors that must be taken into consideration, such as the relationship between teachers and administrators, the physical conditions, cleanliness and organization of schools, the attitudes of administrators towards students, personal problems of some teachers, repressed feelings and anger of teachers due to having a negative relationship with other school personnel, school atmosphere etc. All these factors may affect teachers negatively. Therefore, further research should be made regarding how much teachers are affected.

In this research, it is determined that the external anger levels of the primary school teachers are meaningfully lower than those of the branch teachers and administrators. This result matches with the violence committed by teachers towards students in the secondary schools (Mertoğlu, 2013).The anger levels of the teachers working in the primary schools are lower than those of the teachers working with the sixth-,seventh- and eighth- grade students. It is concluded that a part of the teacher's anger is due to difficulties solving problems with their adolescent students.

The nature of this period is that problems and aggression in adolescent groups are higher than in other student groups. For these reasons, the teachers working with adolescent groups may need to receive ongoing training programmes, anger management seminars, personal or group therapies around how to control their own anger to solve problems with their students.

In the research, the anger test points of study groups became meaningfully lower than the control groups after participating in these type of programmes (Şahin, 2006; Çetinkaya, 2013; Gündoğdu, 2010 pp.257, 276; Feindler, Ecton,1986, pp.109-123; Duran, Eldeleklioğlu, 2005, pp.267-280; Sütçü, Aydın, Sorias,2010,pp.56-66). For example, it is observed that when adolescent students are socially supported, they start expressing themselves efficiently; the students joining sportive activities have less aggressive behaviour than those who do not. These are the types of approaches that help to eliminate the aggression both in teachers and students (Dil. \& Girgin, 2016; Üzüm, Orhan, Duş, Yerlikaya, Gökgöz, 2016).

The anger management test points of the primary school teachers are $81 \%$ higher than those of the secondary and high school teachers. In addition to this, the external anger test points of the secondary school teachers are meaningfully higher than those of the primary and high school teachers. As a result, it is found out that the primary school teachers have lower trait anger and external anger levels while their anger management levels are meaningfully higher than the other groups.

The anger management of teachers and administrators has meaningfully higher test points than the teachers according to the type of schools and whether they like their professions. It is determined that the teachers who like their professions have meaningfully higher test scores than those teachers who regard their jobs as compulsory. This indicates that teachers who like their professions can be more effective in solving problems with their students.

In many surveys, as a variant, the question of whether teachers like their professions or not, is not asked (Yaman, Türker, 2011;Yöndem, Biçak 2008) and therefore, the results of this survey are not compared. For that reason, it is recommended to have new researches by expanding the sampling group questions.

To summarize, it is recommended to support them through sustainable training programmes and seminars on anger management if the teachers who work with adolescents in the $6^{\text {th }}, 7^{\text {th }}$ and $8^{\text {th }}$ grades have anger management problems.

\section{References}

Ak, İ., \& Sayar, K. (2002). Sociobiological factors in antisocial personality disorder. Journal of Clinic Psychopharmacology, 12(3), 155-158. 
Bandura, A. (1986). Social Foundations of Thought and Action; A Social Cognitive Theory: NJ. Prentice Hall

Benbenisty, R., Astor, R. A., \& Marachi, R. (2006). A National Study of School Violence in Israel. Implications for Theory, Practice, and Psychology, 27(3), 462-470.

Cal1, H. H. (2012). Domestic Violence; An Analysis of A Public Politics; Atatürk University Social Science Journal, 16(2), $1-2$.

Çetinkaya, Ş. (2013). The Effect of Problem Solving Programmes Given to Male Adolescents in High Schools on Problem-Solving Skills, Human Relation Styles and Anger Management. Master's Thesis, Adnan Menderes University, The Institution $f$ Science of Health, Health Nursing Department

Cummings, E. M., Ballard, M., El-Sheikh, M., \& Lake, M. (1991). Resolution and children's responses to interadult anger. Developmental Psychology, 27(3), 462-470. https://doi.org/10.1037/0012-1649.27.3.462

Dil, S., \& Girgin, B. A. (2016). An analysis on the relationship between the anger, despair, and stress management levels and social support perception among nursing students. Journal of Psychiactric Nursing, 7(3), 121-128.

Duran, Ö., \& Eldeleklioğlu. J. (2005). A research on the effects of anger management control programmes with adolescents between the ages of 15 and 18 ages. Gazi University Journal of Gazi Educational Faculty, 25(3). 267-280.

Feindler, E. L., \& Ecton, R. B. (1986). Adolescent anger control: Cognitive behavioral techniques. New York: Pergamon Press.

Forgays, D. G., Deborah, K. F., \& Spielberger, C. D. (1997). Factor structure of state-trait anger expression inventory, Journal of Personality Assessment, 69(3), 497-507. https://doi.org/10.1207/s15327752jpa6903_5

Frenzel, A. C. et al. (2015). Measuring Teachers' Enjoyment, Anger, and Anxiety; The Scale of Teachers' Emotions (TES).

Gündoğdu, R. (2010). An Analysis on the Problem Solutions on Conflicts, Anger and Aggression Levels of the $9^{\text {th }}$-Grade Students for some Variables, Ç.Ü. Journal of the Institution of Social Sciences, 19(3), 257-276.

Healy, M. J. (1997). Development of Child's Brain; Learning From Birth to Adolescence and Development of Human Brain. 127, 130-137.Translation:Dicleli A.B.Istanbul. BZD Publishing.

Kağıtçıbaşı, Ç., \& Cemalcılar, Z. (2017). People from the Past to the Present 9755032290. İstanbul:Evrim Publishing.

Kassinove, H., \& Sukhodolsky, D. G. (1995). Anger Disorders: Basic Science And Practice İssues. Disorders:Definition,Diagnosis (1-26). Washington. https://doi.org/10.3109/01460869509087270

Maşaroğulları, G., \& Koçakgül, M. (2011). Dictionary of Psychology. Nobel Akademik ISBN-9786051331591

Mertoğlu, M. (2013). Type of violence committed by teachers aagainst their students. An analysis of its relationship to several variables. İKU-CEHAMER. Journal of Fasikul, (47), 25-34. Istanbul

Mertoğlu, M. (2015). 2004 profile of some victims of domestic violence in the files of Istanbul criminal courts since 2004 and some of the impacts of "law number 6284 concerning victims, offenders, and type of domestic violence. Dokuz Eylül University, Journal of Faculty of Law, 4, 4331-4353, ISSN1303-6963

Şahin, H. (2006). Anger management training programmes on aggressive children. Journal of Psychology Consultation and Counselling, 26(3).

Spielberger, C. D., Jacobs, G. A., Russell, S. F., \& Crane, R. J. (1983). Assessment Of Anger: The State-Trait Anger scale. In J. N. Butcher, \& C. D. Spielberger (Eds.), Advances In Personality Assessment, (2), 159-187. Hillsdale, N.J: Erlbaum.

Sütçü, S. T., Aydın, A., \& Sorias, O. (2010). The effect of cognitive behavior therapy programmes to eliminate anger and aggression. Ege University Journal Of Turkish Psychology, December, 25(66), 57-67.

Üzüm, H., Orhan, M., Duş, M., Yerlikaya, G., \& Gökgöz, H. (2016). An analysis on anger management styles of individuals doing physical exercises and individuals who do not. Abant İzet Baysal University, Journal of The Institution of Social Sciences, 16(1), 453-469.

Yaman, E., \& Türker, S. (2011). The relationship between the strategies of conflict management of primary school teachers and their anger expression levels. Journal of Academic View, 23(11), 8-10.

Yöndem, Z. D., \& Bıcak, B. (2008). Anger levels and styles of teacher trainees. International Human Science Magazine, $5(2), 12-13$.

\section{Copyrights}

Copyright for this article is retained by the author(s), with first publication rights granted to the journal.

This is an open-access article distributed under the terms and conditions of the Creative Commons Attribution license which permits unrestricted use, distribution, and reproduction in any medium, provided the original work is properly cited. 